\title{
Cognitive linguoecology as a methodological approach to the study of destructive communication
}

\author{
Yana Volkova ${ }^{\text {* }}$ \\ ${ }^{1}$ Peoples' Friendship University of Russia (RUDN University), 6 Miklukho-Maklaya St, Moscow, \\ 117198; Moscow State Linguistic University, 38, Ostozhenka St, Moscow, 119034, Russian \\ Federation
}

\begin{abstract}
The article discusses the possibilities of applying the methodology of cognitive ecology to the agenda of destructive communication. Destructive communication is defined as a special type of interaction, which is based on a destructive communicative intention, which is in turn realized in a number of aggressive communicative actions. However, classifying destructive communication as an exclusively emotional type leaves open the question of the place and role of the rational component of destructiveness in communication. The article proves that it is cognitive ecology as a new direction of cognitive research that can offer a holistic and comprehensive approach to the study of destructive communication. As the main research method, the indicated approach includes a holistic analysis of both linguistic structures and social, situational, biological, i.e. non-verbal components, allowing us to understand the mechanisms underlying the destructive, i.e. ecologically irrelevant, communicative behavior. From the perspective of cognitive ecology, Russian-language situations of open and hidden destructive communication are analyzed in various types of discourse. It is concluded that it is necessary to develop a new interdisciplinary scientific direction cognitive linguoecology, within which language will be considered as a specific tool that ensures the functioning of the entire cognitive system, which will make it possible to understand the mechanisms of ecological behavior of the human being as its subject.
\end{abstract}

\section{Introduction}

In recent years, linguoecological research has gone far beyond the initial idea put forward by E. Haugen [1]. In the works of linguoecologists, it is repeatedly noted that modern humanities are characterized by a tendency towards "ecologicality", which actually means the transfer and use of the concepts and terminology of biological ecology to the field of humanitarian disciplines (see [2]). In 2013, the collective monograph "Emotive linguoecology in modern communicative space" was published, which gave rise to a subsidiary branch of linguoecology and emotiology - emotive linguoecology. The tasks of this discipline include a wide range of scientific problems, ranging from the development of criteria for "emotive ecologicality" (I owe this term to prof. V.I. Shakhovsky) of the statement and ending with the study of the ecological / non-ecological influence of emotions on the processes occurring in language [3]. Based on the postulates of emotive linguoecology, in the process of studying the role of "aggressive" emotions in stimulating non-ecological interpersonal communication, a special type of communication was identified, which was called destructive communication [4].

\footnotetext{
* Corresponding author: y.a.v@list.ru
} 


\section{Theoretical Framework}

\subsection{The Concept of Destructive Communication}

Destructiveness is viewed as a special feature of destructive human activity that is revealed in all spheres of human life. There are several definitions of destructive activity, though a traditional definition would involve disruption of existing objects and systems. The term "destructiveness" was introduced into scientific discourse by Erich Fromm who suggested that one should draw the line between the so-called benign (biologically adaptive) and "malignant aggression not related to the preservation of life." [5] Fromm's concept of destructiveness prompted us to suggest the following definition of destructive communication: "destructive" indicates "intentionally committing aggressive actions with the aim of causing suffering to another individual, without feeling any remorse and/or receiving satisfaction from the committed deeds." [6] Destructive communication is characterized by a destructive intention, i.e. the intention to inflict moral or physical harm on the addressee, implemented in a situation of destructive communication, and the presence of certain markers. Situations of destructive communication are "triggered" by emotions, the verbal and/or non-verbal manifestations of which are available for observation and interpretation. The underlying rationale for destructive communication is a disruptive intention, that is an intent to inflict harm on the communicative partner. The concept of intent causes some controversy since intention it is employed in psychology, philosophy and linguistics, where this term conveys specific meanings. While in philosophy and psychology the concept of intention involves the idea of orientation of consciousness at some object, in psycholinguistics, it is the first stage of generating the utterance, according to A. Leontiev [7]. The concept of intention was introduced into modern linguistics by the followers of J. Austin. Since each speech act has its own speech intention (illocutionary force), the typology of speech acts naturally entails the typology of speech intentions. In discourse, intention becomes a critical discourse-forming parameter. Discourse intention is divides the speech flow into discourses. Thus, the intention to persuade is inherent to publicist discourse, the intention to inform forms informative discourse, and the intention to entertain triggers entertaining discourse, the intention of cognition generates scientific discourse [8]. In terms of Gricean conception, communicative intention consists of two subintentions, the first of which is aimed at producing an effect and eliciting a response from the receiver, and the second - at intention 1 being recognized by the receiver [9]. If we understand communicative intention as a kind of orientation of the addressee's consciousness at the achievement of the goal, for the sake of which he enters into communication, then we should realize that intent cannot be identified as some internal event that goes before the action. Ch. Taylor stated: "When the action is successful, voluntary and not forced, the intention is embodied in it." [10], and we base our understanding of intention on it. In practice, it may mean that if somebody addresses you as "a nosy old cow", it is not exactly a lapse. Other parameters of destructive communication include the presence of verbal and/or non-verbal clues of aggression in the communicative situation; verbal and/or nonverbal emotional clues of the addresser's negative reaction, and (optional) the indicators of the addressee's positive reaction to the addresser's suffering. Thus, the following definition of disruptive communication can be suggested: it is a specific kind of intentional emotional communication, the purpose of which is to cause moral and/or physical harm to the addresser.

\subsection{Destructive communication from the perspective of emotive linguoecology}


The original research on emotive linguoecology revealed the major parameters of emotively ecological communication which include positive attitude, politeness, avoidance of negative assessment of the interlocutor, emotional tuning with the subject, respect for the communicative partner, the so-called emotional tenderness, correct (both grammatically, lexically and stylistically) speech, etc. The most important parameter of the ecologicality of human communication is ethics, which defines the ethical function of emotions, closely related to the aesthetic function [11].

Proceeding from the fact that the features of ecological communication at the interpersonal level are anti-conflict character, non-categoricalness, non-impositiveness, glorification (increasing the communicative status of communication partners) and emotional restraint [12], it was shown that destructive communication cannot be characterized with these features. The main characteristics of destructive communication are emotional inconsistency, conflictogenity / intolerance, inadequate communication tone / communicative style, violation of communicative norms, a mindset to denigrate the communicative status of a partner [13]. Further studies of destructive communication have demonstrated the spread of a destructive type of communication in institutional discourses (political, media, business, pedagogical), which made it possible to add the following criteria to the above characteristics: the reliability of the information [14], the thematic uniformity of information distribution and the completeness of the event-related content reflection [15]. There were also identified communicative types who practice destructive communication (the boor, the jealous person, the blackmailer, and some others), but this list is far from complete, because destructive communicative behavior seems to be very attractive for a certain type of personality due to its ambiguous nature.

The issue of emotive (non)ecologicality of destructive communication comes to prominence, if we consider this type of communication from the perspective of emotive linguoecology. Of particular interest is the implementation of aggressive catharsis, i.e. imaginary or real discharge of aggressive emotions. This hypothesis goes back to Aristotle, who believed that tragedy "through compassion and fear" accomplishes "purification (catharsis) of such affects" [16]. In other words, the fear and compassion reproduced on stage relieve the audience from these affects. In the modern epoch, the concept of catharsis was successfully applied by S. Freud and J. Breuer in their "hydraulic" model of aggression [17], and then refined D. Dollard and his colleagues [18]. However, in psychology already in the1950-s, the usefulness of aggressive catharsis was questioned: despite the fact that some experimental studies confirmed the positive effect of aggressive catharsis (see, in particular, the hypothesis of catharsis in mass communications by S. Feshbach), a number of published data contradicted this conclusion (see [19, 20] and others). Moreover, some of the experiments indicated that catharsis enhances further aggressive reactions in the subjects $[21,22]$. The bottom line can be summed up with a quote from D. Goleman: "Outbursts of rage typically pump up the emotional brain's arousal, making people feel more anger, not less." [23]

However, if we turn to the model of aggressive catharsis from the perspective of cognitive linguistics, the role of the very idea of aggressive catharsis in the naive conceptualization of destructive emotions is extremely high. Scholars can endlessly write and talk about how useless and bad "splashing out" aggressive emotions is from both physical and moral positions, but the language won't give up this model of behavior. In fact, this model is reflected and supported in a number of idiomatic expressions both in Russian and English. Such Russian idiomatic expressions as vymestit' zlo, sorvat' zlost' / gnev na kom-libo / chem-libo, otvesti dushu, otorvat'sya na kom-libo, ottyanut'sya na komlibo (take it out on smb, give vent to one's feelings), metaphorical expressions reflecting the conceptual metaphor of destructive emotions as a hot substance in a container (za)kipet', kipyatit'sya, vzryvat'(sya), burlit', vspylit', vypuskat' par, napirat', perepolnyat' (boil, 
explode, seethe, flare up, let off steam) are a testify to the relevance and popularity of the idea of aggressive catharsis in naive consciousness.

In the Russian language, for example, there are a certain number of metaphorical expressions that verbalize destructive emotions. These expressions generally obey the cognitive scenario of emotion as a hot liquid in a container: boil - explode / let off steam cool down. The metaphor of the container, ANGER / RAGE / HATE IS HOT LIQUID IN A CLOSED VESSEL, implements a cognitive scenario common to the destructive emotions, in which the idea of losing control over the emotion and over one's behavior comes to the fore, which consequently poses a danger for everyone - for the subject $\mathrm{him} /$ herself and the people around him/her. Thus, in this metaphor, tranquility and relaxation follow the "explosion", that is, it is the "release" of the destructive emotion outward that brings calm and comfort. It is known that language plays an essential role in the conceptualization of emotional states. From a physiological point of view, stereotyped perception of emotion is formed according to the principle of conditioned reflexes. The constant repetition of the same set expressions leads to the fact that their perception occurs automatically, without the participation of higher consciousness. At the level of the subcortex, a positive assessment is fixed and consolidated: if you have "given vent to your feelings", you feel better. Thus, language introduces a "cathartic" model of behavior into naive consciousness, cutting off the rational component. In this regard, the conclusion of psychologists H. Thomae and H. Kächele is worth mentioning. The scholars suggest that "the satisfaction from aggression is incomparable with the satisfaction of hunger or the pleasure of orgasm, since the satisfaction of aggressive-destructive impulses serves to restore the infringed self-esteem. The fact that a person feels better after emotional release than before is obviously related to the release from tension. But this tension also arises reactively and is based on fantasies in the broadest sense of the word." [24]

Thus, in the assessment of the emotive ecologicality of destructive communication, some contradictions arise: on the one hand, for the object of destructive communication, destructiveness in communication is always non-ecological - it does not matter whether the insult was justified or not, while the subject of destructive communication often enjoys his/her destructive actions. Bolstering one's own status in communication by denigrating the opponent, the experienced feeling of satisfaction from the sufferings of the victim allow us to say that for the subject of destructive communication, this type of communication is a completely ecological "habitat". Numerous examples of catharsis of aggressive emotions indicate that in many cases it is impossible to unequivocally assess the communication situation as emotively (non)ecological, relying only on the semantics of linguistic units.

\subsection{Cognitive linguoecology as a methodological approach}

It seems that studying destructive communication in the framework of emotive linguoecology could be considered somewhat simplistic, since the destructive type of communication is based not just on biological, but on cognitive emotions, i.e. emotions mediated by the human cognitive system. Older children, adolescents and adults assess everything they encounter not only at the level of physiology, but also at the level of personal impact. The animal becomes furious when someone threatens to trespass its territory or deprives it of food; a child becomes enraged when he is teased or when he is treated unfairly, since, as E. Fromm writes, the vital interests of a person are much broader than that of an animal [25].

Thus, the analysis of the semantics of emotive linguistic units in destructive communication seems insufficient to determine the degree of ecologicality of the statement. The concept of cognitive ecology - a methodological approach in which a cognitive agent or a cognizing subject is viewed as a component of a cognitive system - seems to us the 
optimal methodological solution for studying destructive communication. This approach is based on the concept of a cognitive system, which offers information analysis for decision making. The decision-making cycle is, in turn, a combination of sensory perception and assessment of an event, followed by an interpretation of this event with the involvement of the individual's life experience. A. Kolmogorova defined precisely the place of the concept of cognitive systems in linguoecology. She mentions that in terms of cognitive linguistics, an ecological approach requires the choice of "a unit of analysis that would keep intact, holistic, subtle interweaving of connections existing between different elements of the cognitive system, while focusing on its verbal communicative component at the same time." [26] According to the scholar, if we use this holistic approach, a cognitive system will acquire new characteristics that are invisible to the researcher looking at it from a different angle.

\section{Suggested methodology and sample analysis}

\subsection{Methods}

An ideal method for studying destructive communication in the framework of cognitive linguoecology would be an experiment similar to the one conducted in the project "Language as it is: Russian multimodal discourse" under A. Kibrik. The methodology of the project is as follows: the experiment involves four participants, two of whom watch a short film. The first viewer is tasked with telling what he/she has just seen to the third participant, the second viewer supplements the story of the first viewer, and the forth participant is trying to understand the story and asks questions. During the experiment, the participants wear eye-tracking glasses that record the movements of the subjects' eyes during the experiment; there are some special devices which register all actions performed by the experimental subjects. After that, every detail of the communicative interaction between the subjects is analysed and fixed, prosodic features, hand gestures, and eye movements being individually described [27]. Unfortunately, this method can be applied to the study of destructive communication only partially since situation of destructive communication should be observed and analysed in real life situations, not in laboratory conditions. So, we suggest using a complex assessment technique which includes interpretive analysis of a communicative situation from the perspective of the discursive norm that transforms the discourse sample model into a destructive one. The assessment also includes the method of defining the emotive valency of the word, the analysis of a word's inner form, as well as the introspection method. Besides, to assess the ecological aspect of the communicative situation, one needs to provide a thorough analysis of the broader context, i.e. to include the extralinguistic background of the communicative situation and assess its pragmatic effect.

\subsection{Discussion}

Below, an example of the linguoecological assessment of some situations of disruptive communication is provided. Let us focus on the concept of latent aggressiveness, namely, the lingoecology of this type of aggression. This term has been interpreted differently by researchers. We believe that it was F. Riemann who most accurately described its manifestations: "Some people express aggressiveness in the form of over-correctness, abusing their power and hiding the motives of their behavior even from themselves, referring to the inviolability of the rules and the importance of the duty they perform." [Riemann, www] From the perspective of real-life communication, the situations where 
latent aggressiveness is manifested, are rather hard to reveal and analyze. We see two major reasons for this. First, it is hardly possible to track the main criterion of disruptive communication - a destructive intent. For some reasons, it may remain concealed even from the communicative subject. Second, the borderline between reasonable and unreasonable is sometimes very fine, and it might take great patience and long time to decide whether a particular situation may be labeled destructive. The case under consideration refers to the notorious manager of France Telecom Didier Lombard. In 2012 in France, an investigation was opened against him and France Telecom's top managers because of 35 suicides of the company's employees. Former chief executive Didier Lombard, nicknamed "CEO of Suicides", was accused of bullying, "moral harassment" and driving to suicide. Newspapers wrote about the physical humiliation, constant insults of the company's employees which led to the terrible situation in the company. Didier Lombard's response is of interest to us: the top manager did not sympathize with the victims and their families. On the contrary, he was convinced that the he had done his best to maintain jobs in the company. We do not have access to the case materials but some published fragments can prove that the employees were suffering from excessive workload, humiliation, verbal abuse, and other kinds of disparagement at work (See: (https://www.bbc.com/news/worldeurope-48948776 (date of access - 28.08.2020)). Lombard was sentenced to imprisonment. His behavior allows us to assume the implemented tactics of communicative sadism, which we consider one of the specific tactics of destructive communication. A communicative sadist draws satisfaction from his/her destructive communicative activity; he/she does not sympathize with his victim and believes in his own moral righteousness and superiority. Since this kind of behavior ruins both the addressee's and addresser's personality, it can hardly be qualified as ecological.

Another example is taken from real-life communication. A woman is standing in a queue in a clinic. An elderly man next to her makes some remark about her standing too close to him. The woman produces a flow of obscene words causing shock and indignation from the people in the queue who try to stop the flow and "protect" the man. A surprised woman reacts with a phrase, "Why should I keep patient with this old he-goat?" For the woman, her reaction looks perfectly normal and adequate to the "insult". If we regard this situation from the perspective of the people in the queue, both verbal and nonverbal markers indicate the negative assessment of the woman's behaviour, while the woman was satisfied with her offensive actions. Nevertheless, the fact that she finally addressed the the other people in the queue with a kind of explanation of her action indicates that the whole communicative situation was uncomfortable for her as well, and the overall ecologicality of the communicative act can be regarded negative.

When analyzing situations of destructive communication from linguoecological perspective, a special attention should be paid to the semantics and meaning of nonverbal elements. In disruptive communication, kinetic elements often represent a certain transition step from an aggressive emotional state to direct verbal or physical aggression. Besides, a number of aggressive manual gestures such as jerking one's middle finger, shaking fists, etc., effectively transform a communicative situation into a non-ecological one. The obscene gesture of jerking the middle finger is widely used in Russia and can instigate physical aggression. In Russia, there have been cases when people were sued in court for demonstrating their middle fingers. But how non-ecological is this gesture for Russianspeakers? We conducted a brief survey, in which 52 respondents took part. All of them were motorists, both sexes, age distribution between 20 and 48 . They were asked to imagine and describe their actions if another driver on the road shows them a middle finger. $55.8 \%$ responded emotionally. Some subjects in this group described their reaction as highly aggressive: they called the offender 'mudak', 'urod' (freak), and said they would willingly perform some aggressive actions, for example, cut off the offender's car or force 
him/her to stop and then 'have it out with a car lever'. $13.4 \%$ of the subjects chose to ignore this gesture, though they confessed that they would later feel irritated, indignant or offended. $7.6 \%$ of informants replied that they would react with some humorous undertone.

If we look at the results of the survey, it may be regarded as self-evident that the middle-finger gesture can be attributed to the gestures of non-ecological communication as it causes anger and hostility in the addresser. Nevertheless, there could be situations when this gesture triggers a completely different reaction. A subject in our survey mentioned that they would laugh together with the offender if $\mathrm{h} /$ she does not demonstrate any other signs of aggression. This subject also described a situation when a child managed to settle a family conflict by jerking the middle finger during a family row. The parents suddenly burst out laughing thus bringing the conflict to a happy ending. This example can be treated as ambivalently ecological, as the situation could have unfolded according to a different scenario.

Therefore, it can be assumed that non-ecological gestures, including obscene ones, can transform into ecological or ambivalent-ecological depending on such variables as communicative partners' personal character traits and situational awareness. However, it is the original inherent features of the middle-finger gesture that influence the attributing of this gesture to the non-ecological ones.

\section{Conclusion}

Thus, the analysis of any disruptive communicative situation comprises, first of all, the analysis of multimodal material, the purpose of which is to identify the place and function of verbal and nonverbal elements in the implementation of destructive intention and a holistic description of the pragmatic effect of the implemented communication techniques within the framework of the chosen strategy of destructive communication. Only in the case of a comprehensive assessment of such an interaction is it possible to assess the linguoecological impact of a certain communicative act.

\section{Acknowledgments}

This paper was financially supported by the Russian Foundation for Basic Research, grant No. 20-012-22046.

\section{References}

1. E. Haugen, The Ecology of language, Standford: Standford University Press (1972)

2. A.P. Skovorodnikov, Ekologiya russkogo yazyka. Slovar' lingvoekologicheskih terminov [Ecology of the Russian language. Dictionary of linguo-ecological terms], Moscow: Flinta Nauka (2017) (in Russ.)

3. Emotivnaya lingvoekologiya v sovremennom kommunikativnom prostranstve [Emotive linguoecology in modern communicative space]: coll. works, V.I. Shakhovsky (ed.), Volgograd: Izd-vo VGSPU «Peremena» (2013) (in Russ.)

4. YA.A. Volkova, Destruktivnoe obshchenie $v$ kognitivno-diskursivnom aspekte [Destructive communication in the cognitive-discourse aspect], Volgograd: Izd-vo VGSPU «Peremena» (2014) (in Russ.)

5. E. Fromm, Anatomiya chelovecheskoj destruktivnosti [The anatomy of human destructiveness], Moscow, Respublika (1994) (in Russ.) 
6. YA.A. Volkova, Destruktivnoe obshchenie $v$ kognitivno-diskursivnom aspekte [Destructive communication in the cognitive-discourse aspect], Volgograd: Izd-vo VGSPU «Peremena» (2014) (in Russ.)

7. A.A. Leont'ev, Osnovy psiholingvistiki [Fundamentals of Psycholinguistics], Moscow (1999) (in Russ.)

8. N.I. Klushina, Intencional'nyj metod $v$ sovremennoj lingvisticheskoj paradigme [Intentional Method in the Modern Lingvuistic Paradigm], Mediaskop 4 (2012). URL: http://mediascope.ru/node/1242 (Accessed 10 October 2020) (in Russ.)

9. H.P. Grice, Found. Lang. 4, 3, 225-242 (1968)

10. Ch. Taylor, Action as expression, in Intention and Intentionality, C. Diamond and J. Teichman (eds), Brighton: The Harvester Press, pp. 73-90 (1979)

11. V.I. Shahovskij, Dissonans ekologichnosti v kommunikativnom kruge: chelovek, yazyk, emocii [Dissonance of ecologicality in the communicative circle: person, language, emotions], Volgo-grad, izd-vo IP Polikarpov I.L. (2016) (in Russ.)

12. S.S. Takhtarova, Kategoriya kommunikativnogo smyagcheniya: kognitivno-diskursivnyj $i$ etnokul'turnyj aspekty [Category of communicative mitigation: cognitive-discursive and ethnocultural aspects], Author's abstract. dis. Dr. philol. Sciences, Volgograd (2010) (in Russ.)

13. YA.A Volkova, Destruktivnost' kak harakteristika neekologichnogo mezhlichnostnogo obshcheniya [Destructiveness as a characteristic of non-ecological interpersonal communication], in Emotivnaya lingvoekologiya $\mathrm{v}$ sovremennom kommunikativnom prostranstve: kol. monografiya / nauch. red. prof. V.I. Shahovskij Shahovskij [Emotive linguoecology in modern communicative space], Volgograd: Izd-vo VGSPU «Peremena», pp. 323-336 (2013) (in Russ.)

14. N.N. Panchenko, Ekologichnost' kommunikacii skvoz' prizmu dostovernosti informacii [Ecologicality of communication through the prism of information reliability], in Emotivnaya lingvoekologiya $\mathrm{v}$ sovremennom kommunikativnom prostranstve: kol. monografiya / nauch. red. prof. V.I. Shahovskij [Emotive linguoecology in modern communicative space], Volgograd: Izd-vo VGSPU «Peremena», pp. 374-387 (2013) (in Russ.)

15.S.V. Ionova, Priznaki ekologichnosti i problema ih vydeleniya v lingvoekologii [Signs of ecologicality and the problem of their isolation in linguoecology], in Emotivnaya lingvoekologiya $\mathrm{v}$ sovremennom kommunikativnom prostranstve: kol. monografiya / nauch. red. prof. V.I. Shahovskij Shahovskij [Emotive linguoecology in modern communicative space], Volgograd: Izd-vo VGSPU «Peremena», pp. 89-97 (2013) (in Russ.)

16. Aristotle, Poetika [Poetics], Collected works in 43 voumes, 4, Moscow, pp. 645-680 (1984) (in Russ.)

17. S. Freud, Sobranie sochinenij v 26 t. T. 1 Issledovaniya isterii [Collected works in 26 volumes], 1, Studies of hysteria]. Izd-vo «Skifiya» (2020) (in Russ.)

18. J. Dollard, L. Doob, N.E. Miller, O.H. Mowrer, R.R. Sears, Frustration and aggression, New Haven, Conn.: Yale University Press (1939)

19. M. Kahn, JPSP 3, pp. 278-286 (1966)

20. S.K. Mallick, B.R. McCandless, JPSP 4, pp. 591-596 (1966)

21. A. Buss, Aggression Pays, in The Control of Aggression and Violence, NY, London: Academic Press, pp. 7-18 (1971)

22. R.G. Geen, M.B. Quanty, Adv. Exp. Soc. Psychol. 10, pp. 1-37 (1977)

23. D. Goleman, Emocional'nyj intellek [Emotional intelligence], M.: AST: AST Moskva: Hranitel' (2008) (in Russ.) 
24. H. Thomae, H. Kächele, Sovremennyj psihoanaliz. T. 1. Teoriya [Modern psychoanalysis. Vol. 1. Theory], Moscow: Izdatel'skaya gruppa «Progress»— «Litera», Izdatel'stvo Agentstva «YAhtsmen» (1996) (in Russ.)

25. E. Fromm, Anatomiya chelovecheskoj destruktivnosti [The anatomy of human destructiveness], Moscow: Respublika (1994) (in Russ.)

26. A.V. Kolmogorova, Ekologiya yazyka $i$ kommunikativnaya praktika [Ecology of language and communicative practice] 3, pp. 19-28 (2019) (in Russ.)

27. A.A. Kibrik, Psihologicheskij zhurnal [J. Psych.] 39, 1, pp. 70-80 (2018) (in Russ.) 